\title{
Impact of ICT on Students' Academic Performance: Applying Association Rule Mining and Structured Equation Modeling
}

\author{
Mohammad Aman Ullah ${ }^{1}$, Mohammad Manjur Alam ${ }^{2}$, Ahmed Shan-A-Alahi ${ }^{3}$ \\ Mohammed Mahmudur Rahman ${ }^{4}$, Abdul Kadar Muhammad Masum ${ }^{5}$, Nasrin Akter ${ }^{6}$ \\ Dept. of Computer Science and Engineering \\ International Islamic University Chittagong \\ Chittagong-4203, Bangladesh
}

\begin{abstract}
Information and communication technology (ICT) plays a significant role in university students' academic performance. This research examined the effect of ICT on the students' academic performance at different private universities in Chittagong, Bangladesh. Primary data have been collected from the students of those universities using a survey questionnaire. Descriptive Statistics, Reliability Analysis, Confirmatory Factor Analysis, OLS regression, Structured Equation Modeling (SEM) and Data Mining algorithms such as Association rule mining and éclat have been employed to evaluate the comparative importance of the factors in identifying the academic performance of the students. From a statistical and mining perspective, overall results indicate that there is a significant relationship between ICT use and students' academic performance. Also, student's addiction to ICT has a significant influence on the comparative measurement in identifying the academic performance of the students. Finally, some recommendations are provided on the basis of the findings.
\end{abstract}

Keywords-Information and Communication Technology (ICT); student; academic; performance; association rule mining

\section{INTRODUCTION}

The application and effect of Information and Communication Technology (ICT) is considered to be a topic of interest in different areas of real life mostly in education. Educators can now use ICT as a tool that allows modifying the instructional approach in the classroom in order to get better students' performance. Learning institutions are adopting ICT based instructional approach and presenting ICT oriented academic programs. Recently, the Government of Bangladesh has also adopted the use of ICT in the Bangladeshi educational Institutions (home and abroad), giving the importance on this topic. Therefore, students own the ICT facilities for both the academic and non-academic purposes using diverse smart devices and the internet. The use of the ICT in both the academic and non-academic purposes poses the demands to evaluate the students' honesty and the academic performance. Therefore, the objectives of this research are:

1) To uncover the effect of ICT on the academic performance of students at various universities in Chittagong, Bangladesh.

2) To find the relationship between the use of ICT for academic and non- academic purposes by students
To meet the objectives, the data were collected from different private universities of Chittagong, Bangladesh. Descriptive statistics, reliability analysis, Confirmatory Factor Analysis, OLS regression, path analysis and data mining algorithms such as Association rule mining and éclat have been employed to weigh up the comparative significance of the features. The overall results from statistical and data mining analysis indicated that, there is a statistically significant relationship between ICT use and students' academic performance. Also, student's addiction to ICT has a significant influence in comparative measurement in identifying the academic performance of the students. But, the overuse of ICT hampers outcome to a large extend.

\section{BACKGROUND}

The inadequate or lack of ICT facilities appears as significant barriers in students ICT usage. Although students' perceptions are explained in diverse studies as important significant variables to analyze ICT usage, which only depends on enough ICT facilities [7-10], [17], [27]. In conducting multi-media classrooms ICT infrastructure was found to play a significant role [17]. However, Students are not using ICT always for an academic purpose; however, it can be used for the different purposes. For instance, students might use ICT to make class equipment or for individual use [27]. The application of ICT and its effect on student throughput in university education was not reflected to be ideal so far; rather it shows mixed results in the previous study. Previous research has failed to give a logical idea regarding the con- sequence of ICT on students' success. Firstly, some literature could not show a real outcome of ICT on students' perfor- mance in university education. There are very rare experiential support about the influence and efficacy of ICTs on students' academic performance at university level both in developed and underdeveloped countries [29-31]. The research done so far does not clearly reflect pure effects of ICT on student's academic achievements [25], which on the other hand demands the synchronization and regularity regarding the ICTs effect due to methodological restrictions [3]. There are many factors found by different empirical studies for performance improvement at the university level, but neither of the study emphasizes on the ICT use, rather emphasized on how it was 
used [23]. The research related to the use of ICT in teaching and learning by teachers has been done in several surveys [6] [26].

As per the surveys conducted by [24][12], the students of colleges and universities in developed countries use the ICT in all their learning activities. But, due to the over accesses of amusing materials through ICT tools hamper their overall performance [14][16][19][28]. They have conducted their survey in Bangladesh and Indonesia, respectively, and found that, about $80 \%$ of the respondents do not agree that the ICT is useful in improving the academic performance; they rather think it as a source of entertainment. In [1], the authors reported the totally different result. According to his survey of various Bahraini universities, students are more motivated to learn through ICT and thus improve students' performance. A Similar result was found by [11][13][22]. A Result Prediction System was developed by [4] to carry out association rule mining automatically on the collection of earlier student's results and predicts the current students' results. Before it, they have also clustered the subjects on the basis of unique criteria of the subjects. A study was conducted on 320 undergraduate students in Ghana to find the impact of some selected ICT devices in students' academic performance. They have conducted statistical experiments such as descriptive statistics and regression in their study and found that, tools such as email intensify the student's academic performance [18].

Consequence of ICT on students' academic outcome of four Saudi Universities was investigated by [5] in the study they have used structure equation modeling for validating their research model. Their findings show that use of ICT increases students' performance, in particular women, but the university IT course has no influence on the overall academic outcome.[2] applied the propensity score matching method to identify the consequence of ICT use on academic achievement by the school students in Argentina. Their study found no significant relationship between ICT use and academic program. So, it is evident from the literature review that, the performance may or may not improve due to ICT use; it also depends on other factors. This study tries to find the exact association between these factors and impart the real picture.

\section{Methodology And Data Collections}

The data have been collected for this study from different private universities of Chittagong, Bangladesh such as International Islamic University Chittagong (39.5\%), Premier University Chittagong (21.4\%), BGC Trust University (18.6\%), Port City International University (9\%), Chittagong Independent University (9\%), and East Delta University $(2.4 \%$,$) from 2^{\text {nd }}$ to $8^{\text {th }}$ semester students. A total of 210 student data has been collected randomly using a structured questionnaire during the spring 2018 semester. For determining the sample size, the "rule of thumb is larger than 30 and less than 500" [20-21] was maintained. Questionnaires were designed by two parts. Part A was the basic information and part B was the different dimension of students' academic performance by using the 5-point Likert scale. Part A was collected using the features such as Name, University Name, Semester, Department, Gender, Use of Technology, Regularly Internet Browsing Time, Browsing Period, and CGPA. On the other hand, the information used in part B has been discussed in Table II. The study was performed using the Statistical Package for Social Sciences (IBM SPSS Statistics, Version 24.0), STAT 12, Smart PLS3 and R programming language.

\section{RESUlt AND ANALYSIS}

\section{A. Background Characteristics of Respondents}

This is undertaken with a view to giving an idea about the dataset. Percentage method was used to describe the background characteristics of this dataset. The implication of Table I is that most of the respondents 132 (62.9\%) were males while only $78(37.1 \%)$ of them were females. The study also implies that, $26.7 \%$ of students use the internet for about 1 to 2 hours, $24.8 \%$ for three hours, and $47.6 \%$ for more than 4 hours daily. Table I also reveal that $96.7 \%$ students browse the internet regularly for different purposes. According to the findings of the research, half $(50.5 \%)$ of the students uses a laptop on their academic purpose, $34.3 \%$ have access only to the internet for their academic purpose, $49.0 \%$ of the students use the internet solely for academic purposes. $67.7 \%$ of the students' use the ICT in non-academic purpose. This research found that, students with CGPA $<3$ is $28.1 \%, 3-3.3$ is $38.6 \%$ and $3.5-4.00$ is $33.6 \%$.

\section{B. Descriptive Statistics}

The individual items in the Questionnaire, Indicators of five original dimensions and their means, standard deviations, and result of reliability items (Cronbach's Alpha if Item deleted) are performed in Table II. The overall mean and standard deviation of different items is 1.946 and 0.626 respectively. The Result of reliability items in SPSS shows that, there is an internal consistency between the items in questionnaire related to the students' academic performance. The overall Corbadis Alpha is 0.844 .

TABLE. I. BASIC INFORMATION PROFILE

\begin{tabular}{|l|l|l|l|}
\hline Variables & Category of variable & Frequency & Percent (\%) \\
\hline \multirow{4}{*}{ Gender } & Male & 132 & 62.9 \\
\cline { 2 - 4 } & Female & 78 & 37.1 \\
\hline \multirow{4}{*}{$\begin{array}{l}\text { Internet Browse } \\
\text { Regularly }\end{array}$} & Yes & 203 & 96.7 \\
\cline { 2 - 4 } & No & 7 & 3.3 \\
\hline \multirow{4}{*}{$\begin{array}{l}\text { Prowsing } \\
\text { Period(Daily) }\end{array}$} & Zero hour & 2 & 1 \\
\cline { 2 - 4 } & 1 to 2 hours & 56 & 26.7 \\
\cline { 2 - 4 } & Three hours & 52 & 24.8 \\
\cline { 2 - 4 } & Four or more & 100 & 47.6 \\
\hline \multirow{3}{*}{$\begin{array}{l}\text { Technof of } \\
\text { Average CGPA }\end{array}$} & Laptop & 106 & 50.5 \\
\cline { 2 - 4 } & Desktop & 30 & 14.3 \\
\cline { 2 - 4 } & personal mobile & 72 & 34.3 \\
\hline \multirow{3}{*}{$\begin{array}{l}\text { Internet use in } \\
\text { Purpose }\end{array}$} & Less than 3 & 59 & 28.1 \\
\cline { 2 - 4 } & $3.0-3.5$ & 81 & 38.6 \\
\cline { 2 - 4 } & $>3.5$ & 70 & 33.3 \\
\cline { 2 - 4 } & Yes & 142 & 67.7 \\
\hline \multirow{2}{*}{\begin{tabular}{l} 
No \\
\hline
\end{tabular}} & & 68 & 32.3 \\
\hline
\end{tabular}


TABLE. II. DESCRIPTIVESTATISTICS OF INDIVIDUAL ITEM SCALE

\begin{tabular}{|c|c|c|c|c|}
\hline $\begin{array}{l}\text { Individual Items in } \\
\text { Questionnaire }\end{array}$ & $\begin{array}{l}\text { Item } \\
\text { indicators }\end{array}$ & Mean & $\begin{array}{l}\text { Standard } \\
\text { Deviation }\end{array}$ & $\begin{array}{l}\text { Cronbach's } \\
\text { Alpha if } \\
\text { Item } \\
\text { Deleted }\end{array}$ \\
\hline ICT in Class Room & IC & 3.219 & 1.003 & 0.827 \\
\hline Multimedia classroom & $\mathrm{IC} 1$ & 3.362 & 1.146 & 0.828 \\
\hline $\begin{array}{l}\text { To count attendance in a } \\
\text { class }\end{array}$ & IC2 & 3.267 & 1.285 & 0.825 \\
\hline $\begin{array}{l}\text { To achieve the } \\
\text { curriculum goals }\end{array}$ & IC3 & 3.286 & 1.273 & 0.826 \\
\hline $\begin{array}{l}\text { Use of ICT by teacher } \\
\text { during lecture }\end{array}$ & IC4 & 3.286 & 1.266 & 0.831 \\
\hline $\begin{array}{l}\text { To take class by the } \\
\text { projector }\end{array}$ & IC5 & 2.895 & 1.057 & 0.827 \\
\hline $\begin{array}{l}\text { Outside the Class } \\
\text { Room }\end{array}$ & $\mathrm{OC}$ & 2.268 & 0.611 & 0.836 \\
\hline $\begin{array}{l}\text { To prepare homework or } \\
\text { assignment }\end{array}$ & $\mathrm{OC} 1$ & 3.21 & 1.235 & 0.843 \\
\hline $\begin{array}{l}\text { Preparation of } \\
\text { examination }\end{array}$ & $\mathrm{OC} 2$ & 2.762 & 1.054 & 0.834 \\
\hline $\begin{array}{l}\text { Watching academic } \\
\text { lecture }\end{array}$ & OC3 & 2.605 & 1.008 & 0.834 \\
\hline Field study & $\mathrm{OC} 4$ & 2.762 & 1.007 & 0.834 \\
\hline $\begin{array}{l}\text { Opinion Towards ICT } \\
\text { Use }\end{array}$ & OT & 1.114 & 0.54 & 0.836 \\
\hline $\begin{array}{l}\text { I spent most of the time } \\
\text { with ICT }\end{array}$ & OT1 & 2.719 & 2.183 & 0.835 \\
\hline $\begin{array}{l}\text { Share personal } \\
\text { presentation and } \\
\text { information. }\end{array}$ & OT2 & 2.852 & 1.425 & 0.837 \\
\hline Addiction of ICT & Ad & 1.215 & 0.451 & 0.837 \\
\hline $\begin{array}{l}\text { Using ICT my academic } \\
\text { productivity decreased }\end{array}$ & Ad1 & 3.224 & 1.288 & 0.843 \\
\hline Playing game in online & $\operatorname{Ad} 2$ & 2.852 & 1.328 & 0.83 \\
\hline Academic Impacts & AI & 1.913 & 0.523 & 0.847 \\
\hline $\begin{array}{l}\text { ICT improves students' } \\
\text { performance on } \\
\text { examinations }\end{array}$ & AI1 & 3.176 & 1.317 & 0.85 \\
\hline $\begin{array}{l}\text { Using ICT subjective } \\
\text { knowledge is good }\end{array}$ & AI2 & 3.144 & 1.278 & 0.842 \\
\hline To find scholarship & $\mathrm{AI} 3$ & 3.276 & 1.206 & 0.849 \\
\hline Overall & 210 & 1.946 & 0.626 & 0.844 \\
\hline
\end{tabular}

\section{Confirmatory Factor Analysis (CFA) and Structured Equation Modeling (SEM)}

CFA has been used to justify the model fit of the hypothesized structure. The following hypothesis has been considered in the Structural equation model:
Hypothesis: There is no statistically significant relationship between the students' use of ICT and their academic performance.

The model shown in Fig. 1 describes the internal consistency of different items along with regression coefficients and R-square value. In order to evaluate the internal consistency of the factor loading, most of the factors exceed the limiting value 0.70 [32] are shown except IC5, OC1, OC2, OT1 AI1, and AI3. The factors IC5, OC1, OC2, OT1, AI1, and AI3 are considered, because their result of reliability items on Cronbach's Alpha is greater than 0.70 . The proposed model explained $34.5 \%$ variance in the academic impact of ICT. Under the reflective measurement model, cronbach's alpha, composite reliability, and the average variance extracted (AVE) are assessed. From Table III it is shown that although Cronbach's Alpha of one variable is low, but composite reliability and the AVE satisfy the minimum cutoff value 0.7 and greater than 0.5 [32]. Although reliability values greater than 0.70 is good, but between 0.60 0.70 is also acceptable if another dimension of the construct's validity is good [15].

Table IV indicates that all construct shows satisfactory discriminant validity, where the diagonal value is larger than the correlations (off-diagonal) for all reflective constructs [32]. Table V reports that, multi-collinearity has not been detected for independent variables (Addiction of ICT, ICT in Class Room, Opinion towards ICT Use, Outside the Class Room). Table VI shows the overall fit of the structural model. It is evident that, addiction of ICT is the most influential effect on students academic impact $\beta=0.565$, followed by Opinion towards ICT use in academic purpose $\beta=0.116$. But ICT use in inner and outer in the classroom has not been significant. The probable reason is that, the teachers' do not use ICT tools in the classrooms or the ICT facilities in different institutions are not well enough. The overall structural model has shown in Fig. 2.

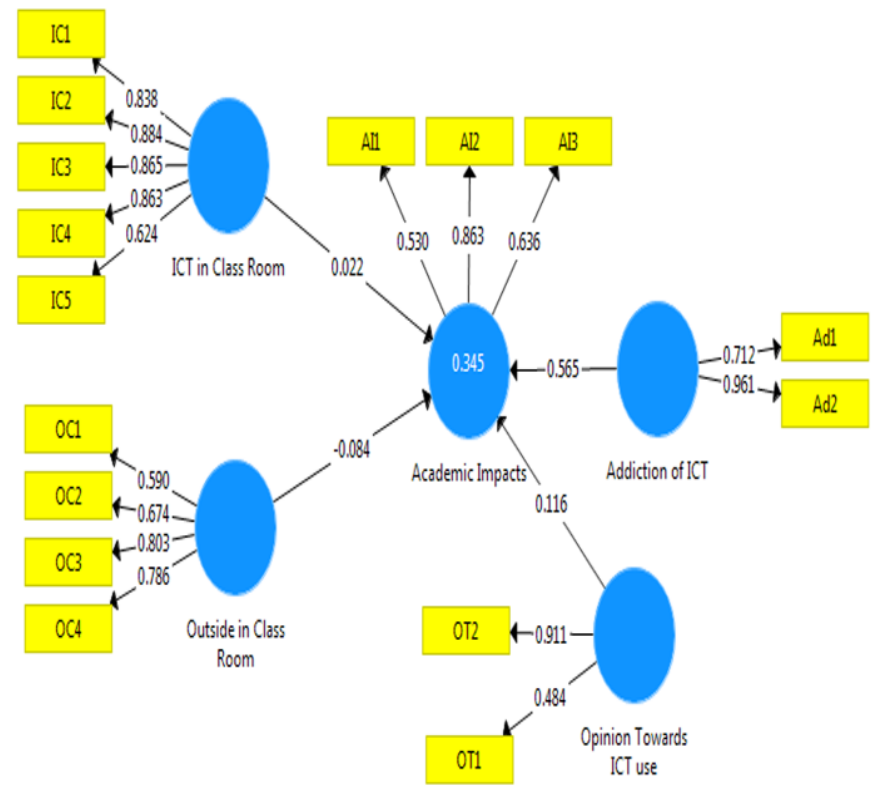

Fig. 1. The Hypothesized Structured Model. 
TABLE. III. CONSTRUCT RELIABILITY AND VALIDITY

\begin{tabular}{|l|l|l|l|}
\hline $\begin{array}{l}\text { Loading } \\
\text { Variables }\end{array}$ & $\begin{array}{l}\text { Cronbach's } \\
\text { Alpha }\end{array}$ & $\begin{array}{l}\text { Composite } \\
\text { Reliability }\end{array}$ & $\begin{array}{l}\text { Average Variance } \\
\text { Extracted (AVE) }\end{array}$ \\
\hline $\begin{array}{l}\text { Academic } \\
\text { Impacts }\end{array}$ & 0.676 & 0.724 & 0.807 \\
\hline Addiction of ICT & 0.837 & 0.831 & 0.715 \\
\hline $\begin{array}{l}\text { ICT in Class } \\
\text { Room }\end{array}$ & 0.879 & 0.91 & 0.673 \\
\hline $\begin{array}{l}\text { Opinion Towards } \\
\text { ICT Use }\end{array}$ & 0.697 & 0.775 & 0.632 \\
\hline $\begin{array}{l}\text { Outside the Class } \\
\text { Room }\end{array}$ & 0.713 & 0.808 & 0.616 \\
\hline
\end{tabular}

TABLE. IV. FACTOR MATRIX SHOWING DISCRIMINANT VALIDITY

\begin{tabular}{|c|c|c|c|c|c|}
\hline Variables & $\begin{array}{l}\text { Acade } \\
\text { mic } \\
\text { Impacts }\end{array}$ & $\begin{array}{l}\text { Addicti } \\
\text { on of } \\
\text { ICT }\end{array}$ & $\begin{array}{l}\text { ICT in } \\
\text { Class } \\
\text { Room }\end{array}$ & $\begin{array}{l}\text { Opinion } \\
\text { Towards } \\
\text { ICT Use }\end{array}$ & $\begin{array}{l}\text { Outside } \\
\text { the Class } \\
\text { Room }\end{array}$ \\
\hline $\begin{array}{l}\text { Academic } \\
\text { Impacts }\end{array}$ & 0.691 & & & & \\
\hline $\begin{array}{l}\text { Addiction } \\
\text { of ICT }\end{array}$ & 0.578 & 0.846 & & & \\
\hline $\begin{array}{l}\text { ICT in } \\
\text { Class } \\
\text { Room }\end{array}$ & 0.228 & 0.372 & 0.821 & & \\
\hline $\begin{array}{l}\text { Opinion } \\
\text { Towards } \\
\text { ICT Use }\end{array}$ & 0.252 & 0.301 & 0.367 & 0.729 & \\
\hline $\begin{array}{l}\text { Outside the } \\
\text { Class } \\
\text { Room }\end{array}$ & 0.187 & 0.355 & 0.555 & 0.504 & 0.718 \\
\hline
\end{tabular}

TABLE. V. COLLINEARITY STATISTICS (VIF)

\begin{tabular}{|l|l|}
\hline Variables & VIF \\
\hline Addiction of ICT & 1.225 \\
\hline ICT in Class Room & 1.535 \\
\hline Opinion Towards ICT Use & 1.384 \\
\hline Outside the Class Room & 1.731 \\
\hline
\end{tabular}

TABLE. VI. PATH COEFFICIENT

\begin{tabular}{|l|l|l|l|l|}
\hline Relationship & $\begin{array}{l}\text { Coeffic } \\
\text { ient }\end{array}$ & $\begin{array}{l}\text { Standard } \\
\text { Error }\end{array}$ & $\begin{array}{l}\text { T } \\
\text { Statisti } \\
\text { cs }\end{array}$ & $\begin{array}{l}\text { P } \\
\text { Valu } \\
\text { es }\end{array}$ \\
\hline $\begin{array}{l}\text { ICT in Class Room -> } \\
\text { Academic Impacts }\end{array}$ & 7.5 & 0.059 & 0.366 & 0.357 \\
\hline $\begin{array}{l}\text { Outside the Class Room -> } \\
\text { Academic Impacts }\end{array}$ & -0.084 & 0.07 & 1.198 & 0.116 \\
\hline $\begin{array}{l}\text { Opinion Towards ICT Use -> } \\
\text { Academic Impacts }\end{array}$ & 0.116 & 0.069 & 1.692 & 0.043 \\
\hline $\begin{array}{l}\text { Addiction of ICT -> Academic } \\
\text { Impacts }\end{array}$ & 0.565 & 0.053 & 10.648 & 0 \\
\hline
\end{tabular}

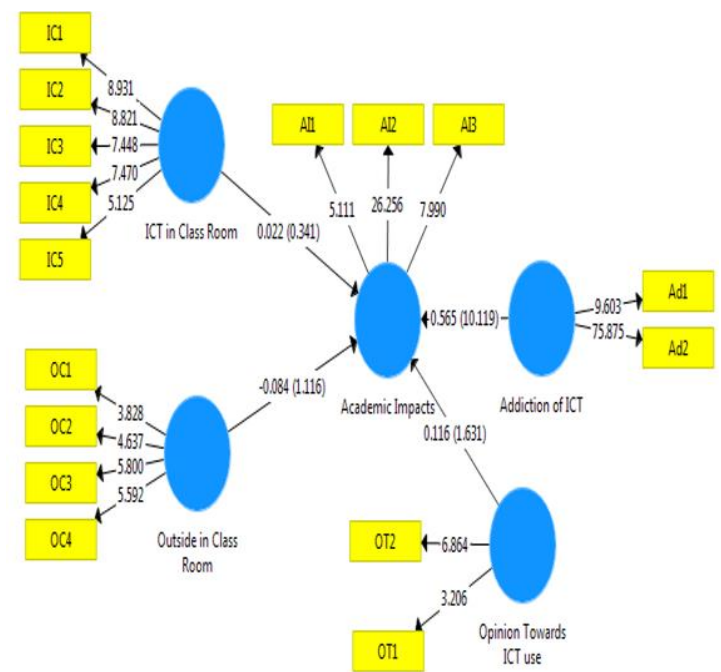

Fig. 2. Path Coefficient with T-Value.

\section{Students Performance Estimation using OLS Regression}

Ordinary least squares regression analyses were also carried out in this study. The academic impact was used as dependent variable and addiction of ICT, ICT in the classroom, opinion towards ICT use, and ICT use outside the classroom was used as independent variables. The proposed model is

$Y=\alpha+\beta_{1} X_{1}+\beta_{2} X_{2}+\beta_{3} X_{3}+\beta_{4} X_{4}+U$

Where, the dependent variable $\mathrm{Y}$ is the Academic impact of ICT, $\mathrm{X} 1=$ ICT in the classroom, $\mathrm{X}_{2}=$ ICT use outside the classroom, $\mathrm{X}_{3}=$ Opinion towards ICT Use, $\mathrm{X}_{4}=$ Addiction of ICT, and $U=$ Disturbance term. The details' regression results have been given below.

Table VII shows the F test for the regression model which evaluates the statistical significance of the overall regression model. The F-value is the mean square regression (3.483) divided by the Mean Square Residual (0.211). The p-value associated with this $\mathrm{F}$ value is very small (0.000). The value of $\mathrm{R}$-square is 0.243 reflects that $24 \%$ of the variation in academic impacts can be predicted from the combination of independent variables ICT in the classroom, outside the classroom, opinion towards ICT use, addiction of ICT. Table VIII shows that, the relative importance of significant dimension is observed by the regression coefficient. By analyzing the results, it is shown that, the variable Addiction of ICT has the highest regression coefficient with the significance p- value (p 0.01). This means that "Addiction of ICT" dimension is the main predictor in the estimation of OLS regression. All the other variables are not significant.

TABLE. VII. SUMMARY OF REgRESSION MODEL AND ANOVA

\begin{tabular}{|l|l|l|l|l|}
\hline Source & SS & df & MS & \\
\hline Model & 13.933 & 4 & 3.483 & $\begin{array}{l}\text { Number of obs =210, F (4, 205) } \\
=16.48\end{array}$ \\
\hline Residual & 43.329 & 205 & 0.211 & $\begin{array}{l}\text { Prob }>\text { F=0 } \\
\text { R-squared = 0.243 } \\
\text { Adj R-squared=0.229, } \\
\text { Root MSE=0.459 }\end{array}$ \\
\hline Total & 57.263 & 209 & 0.274 & \\
\hline
\end{tabular}


TABLE. VIII. REGRESSION COFFICIENT

\begin{tabular}{|l|l|l|l|l|l|l|}
\hline Academic Impacts & Coefficient & Standard Error & \multicolumn{1}{|l|}{ T Statistics } & P>t & \multicolumn{2}{l|}{ 95\% Conf.Interval } \\
\hline ICT in Class Room & 0.025083 & 0.0370895 & 0.68 & 0.5 & -0.048 & 0.0982 \\
\hline Outside the Class Room & -0.03696 & 0.0647209 & -0.57 & 0.569 & -0.1645 & 0.0906 \\
\hline Opinion Towards ICT Use & 0.086031 & 0.0660603 & 1.3 & 0.194 & -0.0442 & 0.2162 \\
\hline Addiction of ICT & 0.536722 & 0.0766979 & 7 & 0 & 0.3855 & 0.6879 \\
\hline Constant & 1.168289 & 0.1381918 & 8.45 & 0 & 0.8958 & 1.4407 \\
\hline
\end{tabular}

\section{E. Data Mining}

In this research, Association rule mining was used, which is one of the famous data mining methods for detecting and extracting useful information from transaction data. From among several association rule mining algorithms, this research mine association rules using both the $\mathrm{A}$ prior and eclat algorithm in $\mathrm{R}$ using a package called a rule. Moreover, these methods generate a large number of available rules and make it difficult to relocate interesting ones. Therefore, this research found the one by applying different support and confidence level. At initial levels, after applying the A prior algorithm with low support and confidence value, total 1592 rules was generated. Later the test was done on different support and confidence values and stops at support value 0.07 and confidence value 0.5 and got 383 association rules. After carefully filtering the rules with confidence value $0.8,131$ quality rules were generated. Fig. 3, 4, 5 and 6 shows the Scatter and a matrix plot of the rules before and after filtering respectively. In Table $\mathrm{X}$ few of them with higher influence is shown. By applying eclat algorithms, total 59 rules were generated. In total 230 rows and 18 columns (details shown in Table IX and Table X), Internet_Browse_Regularly=Yes was found to be a most frequent item and influential factor for CGPA improvement of both the algorithms.

TABLE. IX. Most FreQuent ITEMS

\begin{tabular}{|l|l|}
\hline Items & Frequency \\
\hline Internet_Browse_Regularly=Yes & 203 \\
\hline Gender=Male & 132 \\
\hline Technology=Laptop & 106 \\
\hline cgpa1=Excellent & 105 \\
\hline cgpa1=good & 105 \\
\hline (Other) & 607 \\
\hline
\end{tabular}

TABLE. X. FREQUENT RULES

\begin{tabular}{|c|c|c|c|c|c|c|}
\hline $\begin{array}{l}\text { Sorted } \\
\text { No }\end{array}$ & Lhs & Rhs & Support & Confidence & Lift & Count \\
\hline 15 & $\{$ Technology=Internet, Browsing_Period=Two Hour $\}$ & $\{$ cgpa1=Excellent $\}$ & 0.038 & 0.615 & 1.231 & 8 \\
\hline 16 & $\begin{array}{l}\{\text { Technology=Internet,Internet_Browse_Regularly=Yes, } \\
\text { Browsing_Period=Two Hour }\}\end{array}$ & $\{$ cgpa $1=$ Excellent $\}$ & 0.038 & 0.615 & 1.231 & 8 \\
\hline 18 & $\{$ Technology=Desktop,Browsing_Period=Three Hour $\}$ & $\{$ cgpa1=Excellent $\}$ & 0.029 & 0.6 & 1.2 & 6 \\
\hline 13 & $\begin{array}{l}\{\text { Technology=Desktop, Internet_Browse_Regularly=Yes, } \\
\text { Browsing_Period=Three Hour }\}\end{array}$ & $\{$ cgpa1 $=$ Excellent $\}$ & 0.029 & 0.667 & 1.333 & 6 \\
\hline 17 & $\{$ Technology=Desktop,Browsing_Period=Two Hour $\}$ & $\{$ cgpa1=Excellent $\}$ & 0.014 & 0.6 & 1.2 & 3 \\
\hline 19 & $\begin{array}{l}\{\text { Technology=Desktop,Internet_Browse_Regularly=Yes,Browsing_Period=Two } \\
\text { Hour }\}\end{array}$ & $\{$ cgpa1 $=$ Excellent $\}$ & 0.014 & 0.6 & 1.2 & 3 \\
\hline 6 & $\{$ Technology=Internet,Browsing_Period=One Hour $\}$ & $\{$ cgpa1=Excellent $\}$ & 0.014 & 0.75 & 1.5 & 3 \\
\hline 7 & $\begin{array}{l}\{\text { Technology=Internet,Internet_Browse_Regularly=Yes,Browsing_Period=One } \\
\text { Hour }\}\end{array}$ & $\{$ cgpa1 $=$ Excellent $\}$ & 0.014 & 0.75 & 1.5 & 3 \\
\hline 9 & $\{$ Internet_Browse_Regularly=No,Browsing_Period=Three Hour $\}$ & $\{$ cgpa1=Excellent $\}$ & 0.01 & 0.667 & 1.333 & 2 \\
\hline 10 & $\{$ Technology=Laptop,Internet_Browse_Regularly=No $\}$ & $\{$ cgpa1=Excellent $\}$ & 0.01 & 0.667 & 1.333 & 2 \\
\hline 2 & $\{$ Technology=Internet,Internet_Browse_Regularly=No $\}$ & $\{$ cgpa1=Excellent $\}$ & 0.01 & 1 & 2 & 2 \\
\hline 4 & $\begin{array}{l}\{\text { Technology=Internet,Internet_Browse_Regularly=No,Browsing_Period=Three } \\
\text { Hour }\}\end{array}$ & $\{$ cgpa1 $=$ Excellent $\}$ & 0.01 & 1 & 2 & 2 \\
\hline 11 & $\{$ Technology=Laptop,Browsing_Period=Two Hour $\}$ & $\{$ cgpa1=good $\}$ & 0.076 & 0.667 & 1.333 & 16 \\
\hline 8 & $\begin{array}{l}\{\text { Technology=Laptop,Internet_Browse_Regularly=Yes,Browsing_Period=Two } \\
\text { Hour }\}\end{array}$ & $\{$ cgpa1 $=$ good $\}$ & 0.071 & 0.682 & 1.364 & 15 \\
\hline 14 & $\{$ Internet_Browse_Regularly=Yes,Browsing_Period=One Hour $\}$ & $\{$ cgpa1=good $\}$ & 0.038 & 0.615 & 1.231 & 8 \\
\hline 12 & $\begin{array}{l}\{\text { Technology=Laptop,Internet_Browse_Regularly=Yes,Browsing_Period=One } \\
\text { Hour }\}\end{array}$ & $\{$ cgpa1 $=$ good $\}$ & 0.019 & 0.667 & 1.333 & 4 \\
\hline 3 & $\{$ Technology=Desktop,Browsing_Period=One Hour $\}$ & $\{$ cgpa1=good $\}$ & 0.014 & 1 & 2 & 3 \\
\hline 5 & $\begin{array}{l}\{\text { Technology=Desktop,Internet_Browse_Regularly=Yes,Browsing_Period=One } \\
\text { Hour }\}\end{array}$ & $\{$ cgpa $1=$ good $\}$ & 0.014 & 1 & 2 & 3 \\
\hline 1 & $\{$ Browsing_Period=Zero Hour $\}$ & $\{$ cgpa1=good $\}$ & 0.01 & 1 & 2 & 2 \\
\hline
\end{tabular}




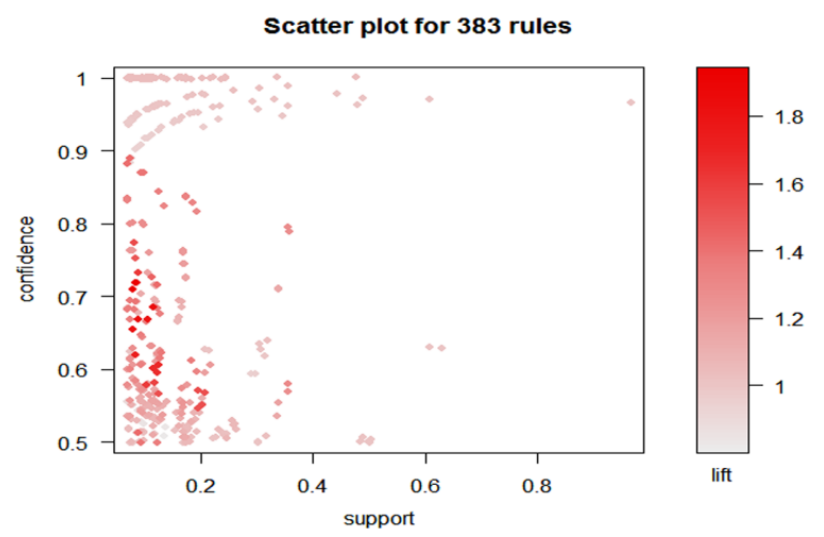

Fig. 3. Scatter Plot of Rules before Filtering.

Matrix with 383 rules

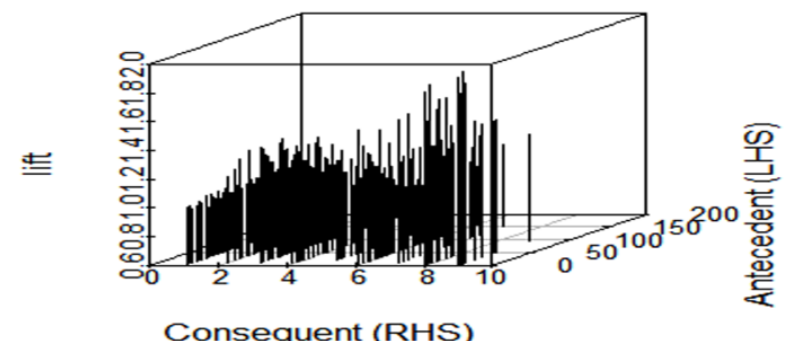

Fig. 4. Matrix Plot of Rules before Filtering.

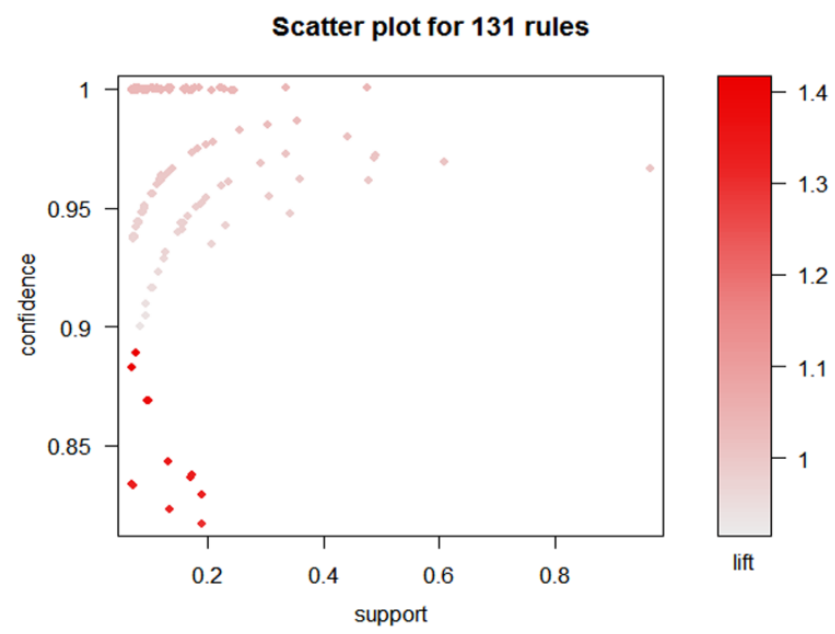

Fig. 5. Scatter Plot of Rules after Filtering.

Matrix with 131 rules

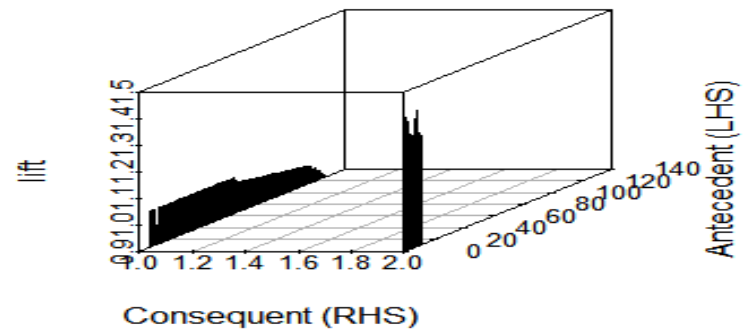

Fig. 6. Matrix Plot of Rules after Filtering.

\section{COMPARISON}

This research compares the OLS regression analysis and path structural equation modeling. Although path analysis is an extension of linear regression model used to examine the relationships between measured variables, but it is a highly flexible and extensible methodology. Tests associated with both methods are satisfied with their assumption. The OLS regression and path structural equation model identify different relationships between variables in the model. Both models include the same predictor and predicted variables in different items. Although statistical tests of significance and an R-square value slightly differ, but the variable "Addiction of ICT" is the main significant comparative predictor in both models. The result from association rule mining also reflects the same, that is, if the student increases the use of ICT then their CGPA improves provided that, they are using ICT in academic purpose.

\section{DISCUSSION}

The findings of the study show that the student 'Addiction of ICT' is the most important predictor in the analysis. This gives the controversial result with the academic impact of ICT. This result also supports the low value of R2 (0.345 and 0.243) in the studied models. From these findings, drawn conclusions are that the student academic result is not only depending on ICT but also has a lot of external and internal factors. Moreover, Students spent most of the time with ICT in nonacademic purpose.

\section{RECOMMENDATIONS}

The authors recommend the following to improve the students' academic performance based on the findings of this study:

- ICT facilities in classrooms should be improved

- Teachers should conduct their classes by using ICT

- Technology should be used for own advancement and should control the unnecessary use of technology.

- Students should use ICT for their academic purposes most of the time.

- All the university should adopt the technology for academic purposes.

- Students should make aware of ICT use in Education

\section{CONCLUSION AND FUTURE WORKS}

In this era, ICT plays an important role in day- to-day activities, including education, so it is high time to evaluate the impact of ICT on education and to ensure its positive use. In this context, this study was carried out using Descriptive statistics, reliability analysis, Confirmatory Factor Analysis, OLS regression, path analysis, and data mining algorithms such as Association rule mining and eclat. The study exposes the negative impact of the academic performance of the students as the use of ICT if it is not used properly. The study also shows that if academic or related institutions take the right steps to use the ICT for academic purposes, education as a whole and students ' academic performance in particular will 
benefit greatly. This study will be extended in future to compare the impact of ICT on the performance of students in private universities with that of students in the public university of the country. The data set will also be enlarged and the prediction from this data set will be included.

\section{REFERENCES}

[1] J. AlAmmary, "Educational Technology: A Way to Enhance Student Achievement at the University of Bahrain", Procedia-Social and Behavioral Sciences, vol. 55, pp. 248-257, 2012.

[2] M. Alderete and M. Formichella, "The effect of ICTs on academic achievement: The conectar igualdad programme in Argentina", CEPAL Review, vol. 2016, no. 119, pp. 83-100, 2017.

[3] A. Aristovnik, "The Impact of ICT on Educational Performance and its Efficiency In Selected EU and OECD Countries: A Non-Parametric Analysis", SSRN Electronic Journal, 2012.

[4] Aziz, A. A., Idris, W. M. R. W., Hassan, H., Jusoh, J. A., and Emran, N. A., "Implementing Aproiri Algorithm for Predicting Result Analysis", GSTF Journal on Computing (JoC), vol.2, no.4, 2018.

[5] W. Basri, J. Alandejani and F. Almadani, "ICT Adoption Impact on Students' Academic Performance: Evidence from Saudi Universities", Education Research International, vol. 2018, pp. 1-9, 2018.

[6] Y. Baek, J. Jung and B. Kim, "What makes teachers use technology in the classroom? Exploring the factors affecting facilitation of technology with a Korean sample", Computers \& Education, vol. 50, no. 1, pp. 224234, 2008.

[7] Beggs, T.A. (2000). Influences and barriers to the adoption of instructional technology, retrieved April 25, 2008, from ht tp://www.mtsu.edu/ itconf/proceed00/beggs/beggs.htm.

[8] J. van Braak, "Factors influencing the use of computer mediated communication by teachers in secondary schools", Computers \& Education, vol. 36, no. 1, pp. 41-57, 2001.

[9] Butler, D. L. and Sellbom, M., "Barriers to adopting technology", Educause Quarterly, vol. 2, pp. 22-28, 2002.

[10] J. Bussey, T. Dormody and D. VanLeeuwen, "Some Factors Predicting the Adoption of Technology Education in New Mexico Public Schools", Journal of Technology Education, vol. 12, no. 1, 2000.

[11] A. Carle, D. Jaffee and D. Miller, "Engaging college science students and changing academic achievement with technology: A quasiexperimental preliminary investigation", Computers \& Education, vol. 52, no. 2, pp. 376-380, 2009.

[12] G. Conole, M. de Laat, T. Dillon and J. Darby, "'Disruptive technologies', 'pedagogical innovation': What's new? Findings from an in-depth study of students' use and perception of technology", Computers \& Education, vol. 50, no. 2, pp. 511-524, 2008.

[13] A. Enriquez, "Enhancing Student Performance Using Tablet Computers", College Teaching, vol. 58, no. 3, pp. 77-84, 2010.

[14] C. Fried, "In-class laptop use and its effects on student learning", Computers \& Education, vol. 50, no. 3, pp. 906-914, 2008.

[15] J. Hair, B. Babin and N. Krey, "Covariance-Based Structural Equation Modeling in the Journal of Advertising: Review and
Recommendations", Journal of Advertising, vol. 46, no. 3, pp. 454-454, 2017.

[16] M. Islam and M. Fouji, "The impact of ICT on students' performance: A case study of ASA University Bangladesh", ASA University Review, vol. 4, no. 2, pp. 101-106, 2010.

[17] K.Mumcu and K. Usluel, "Mesleki ve teknik okul ogretmenlerinin bilgisayar kullanımları ve en- geller", Hacettepe Universitesi Egitim Fakultesi Dergisi, vol. 26, pp.91- 100, 2004.

[18] Nketiah-Amponsah, E., Asamoah, M. K., Allassani, W., \&Aziale, L. K. (2017). Examining students' experience with the use of some selected ICT devices and applications for learning and their effect on academic performance. Journal of Computers in Education, 4(4), 441-460.

[19] Perbawaningsih, Y. (2013). Plus minus of ICT usage in higher education students. Procedia-Social and Behavioral Sciences, 103, 717-724.

[20] Roscoe, J. T. (1975). Fundamental research statistics for the behavioral sciences [by] John T. Roscoe.

[21] Sekaran, U. and Bougie, R., (2010). Theoretical frame- work In theoretical framework and hypothesis development. Research methods for business: A skill building approach, 80.

[22] Sari, A. (2014). Influence of ICT Applications on Learning Process in Higher Education. Procedia-Social and Behavioral Sciences, 116, 4939-4945.

[23] Sife, A., Lwoga, E., \&Sanga, C. (2007). New technologies for teaching and learning: Challenges for higher learning institutions in developing countries. International journal of education and development using ICT, $3(2), 57-67$.

[24] S.Smith, and J. Caruso, "The ECAR study of undergraduate students and information technology", 2010.

[25] Song, H. D., \& Kang, T. (2012). Evaluating the Impacts of ICT Use: A Multi-Level Analysis with Hierarchical Linear Modeling. Turkish Online Journal of Educational Technology- TOJET, 11(4), 132-140.

[26] Turel, Y. K. (2011). An interactive whiteboard student survey: Development, validity and reliability. Computers \& Education, 57(4), 2441-2450.

[27] Ward, L., \& Parr, J. M. (2010). Revisiting and reframing use: Implications for the integration of ICT. Computers and Education, 54(1), 113-112.

[28] Yamamoto, K. (2007). Banning laptops in the classroom: Is it worth the hassles? Journal of Legal Education, 57(4), 477-520.

[29] Youssef, A. B., \&Dahmani, M. (2008). The impact of ICT on student performance in higher education: Direct effects, indirect effects and organisational change. RUSC. Universities and Knowledge Society Journal, 5(1), 45-56.

[30] Youssef, A. B., \& DAHMANI, M. Innovative ICT usage by Higher Education Teachers in Tunisia: A PLS Path Modelling Approach.

[31] Youssef, A. B., Youssef, H. B., \&Dahmani, M. (2013). Higher education teachers e-skills and the innovation process. International Journal of Computer and Information Technology, 2(2),185-19.

[32] Joseph F. Hair Jr., Barry J. Babin \& Nina Krey (2017) CovarianceBased Structural Equation Modeling in the Journal of Advertising: Review and Recommendations, Journal of Advertising, 46:1, 163-177, DOI: $10.1080 / 00913367.2017 .1281777$. 